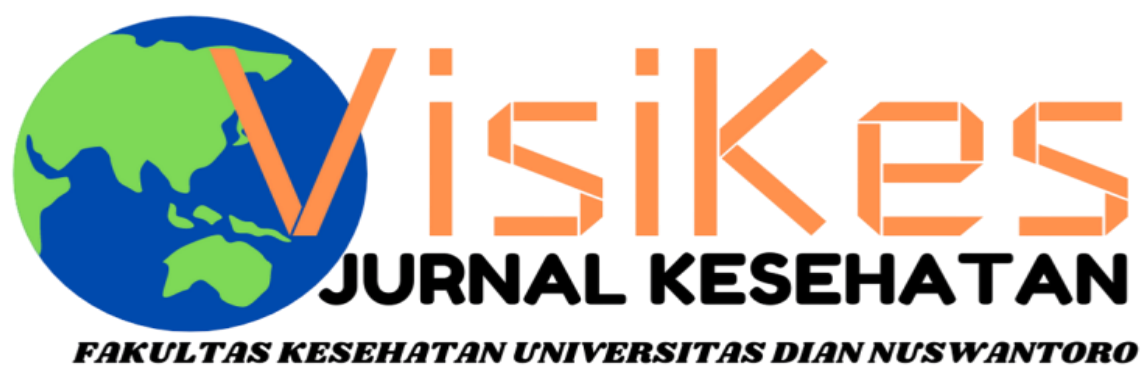

ISSN 1412-3746

FAKULTAS KESEHATAN UNIVERSITAS DIAN NUSWANTORO

Persepsi Mahasiswa Keperawatan Tentang Eskalasi Tenaga Perawat

Rendi Ariyanto Sinanto', Vivi Retno Intening ${ }^{2}$

Risiko kesehatan $\mathrm{Pb}$ dan $\mathrm{Hg}$ pada sayuran di desa Kopeng Kabupaten Semarang

Indira Casheila Anindityo ${ }^{1}$, Nur Endah Wahyuningsih ${ }^{2}$, Yusniar Hanani Darundiati ${ }^{3}$

Analisis Pelaksanaan Program Indonesia Sehat Dengan Pendekatan Keluarga (Pispk) Dalam Capaian Indeks Keluarga

Sehat Di Kabupaten Brebes Tahun 2020 Studi Pada Puskesmas Kluwut Kabupaten Brebes

Rizky Aprilianti Lestari ${ }^{1}$ dr. Antono Suryoputro ${ }^{1}$ Dr. dr. Apoina Kartini. M. Kes ${ }^{1}$

Disiplin Keselamatan dan Kesehatan Kerja melalui pemakaian alat pelindung diri di laboratorium kimia PT Sucofindo

Jakarta

Susan Endah Kartikasari ${ }^{1}$, Tatan Sukwika ${ }^{2}$

Perbedaan Pengetahuan Anemia dan Tablet Tambah Darah (TTD) Sebelum dan Sesudah Pendidikan Kesehatan Melalui

Media Video dan Aplikasi Quizlet

Devita Sari ${ }^{1}$, Gisely Vionalita ${ }^{2}$

Tingkat Pengetahuan Dan Perilaku Mahasiswi Mengenai Legalitas Dan Keamanan Kosmetik

Hani Sri Fitriani, Rizki Siti Nurfitria

Evaluasi Manajemen Dokumen Rekam Medis Di Filing Aktif Rumah Sakit Swasta Kabupaten Semarang

Bobby Anggara Laksana Putra ${ }^{1}$, Retno Astuti Setjaningsih ${ }^{2}$

Tingkat Pengetahuan Gizi Seimbang dan Profil Kesehatan Sopir Bus Antar Kota

Vilda Ana Veria Setyawati ${ }^{1}$, Bayu Yoni Setyo Nugroho ${ }^{1}$

Pengaruh Pengetahuan Dan Motivasi Kerja Terhadap Penerapan Early Warning Score System Di Rsup H Adam Malik Ita Riahna Pinem ${ }^{1}$, Zulfendri', Siti Saidah Nasution ${ }^{3}$

Analisis Penelusuran Masker Sebagai Protokol Kesehatan Saat Pandemi Covid-19 Di Indonesia: Studi Google Trends Ully Febra Kusuma ${ }^{1}$, Nurunnisa Arsyad ${ }^{2}$, Melissa Shalimar Lavinia ${ }^{3}$, Selvia Rahayu ${ }^{4}$, M. Khairul Kahfi , Rizma Adllia Syakurah ${ }^{6}$ Perilaku Hidup Bersih Dan Sehat (Phbs) Dengan Kejadian Sakit Pada Siswa Sekolah Dasar Di Kabupaten Banyumas Windri Lesmana Rubai ${ }^{1}$, Pramesthi Widya Hapsari', Katri Andirini Surijati ${ }^{3}$

Identifikasi Risiko Ganguan Muskuloskletal Pada Pekerja Percetakan Dengan Metode Nordic Body Map

Octavianus Hutapea ${ }^{1}$, Moch.Sahri', Rustam Basuki ${ }^{3}$

Literatur review: Implementasi Bauran Pemasaran 7P Terhadap Tingkat Kepuasan Pasien Di Rumah Sakit

Desi Natalia Marpaung ${ }^{1}$ Ernawaty $^{2}$ Diansanto Prayoga ${ }^{3}$ Syifa'ul Lailiyah $^{4}$

Kelengkapan Informasi Medis Untuk Mendukung Kodefikasi Penyakit Jantung Guna Mewujudkan Kualitas Data Informasi Medis Di Rumah Sakit Islam Sultan Agung Semarang

Dyah Ernawati ${ }^{1}$, Ratna Rifatul Ulya ${ }^{2}$, Arif Kurniadi ${ }^{3}$

Kajian Faktor Kendala Dokter Tidak Menggunakan Aplikasi Wifi Tb Di Kota Semarang

Arif Kurniadi', Evina Widianawati2, Dyah Ernawati ${ }^{3}$

Analisis Pelaksanaan Program Penanggulangan Tuberkulosis Paru Di Puskesmas Purwoyoso Kota Semarang

Nahari Ratu Cempaka Wilis ${ }^{1}$ Hardi Warsono ${ }^{2}$ M. Sakundarno Adi ${ }^{3}$

Hubungan Penggunaan Alat Pelindung Diri (Apd) Dengan Kadar Sgot Dan Sgpt Dalam Darah Pada Petani Padi

Iga Maliga, Rafi'ah

Faktor Risiko Kejadian Stunting Pada Balita di Wilayah Kerja Puskesmas Pandan Kabupaten Sintang

${ }^{1}$ Agustini Elisabet, ${ }^{2}$ Elvi Juliansyah

Peran Suami Dan Petugas Kesehatan Dengan Deteksi Dini Kanker Serviks

Christina Leasa, ${ }^{1}$ Mariene Wiwin Dolang

Analisis Penerapan Protokol Kesehatan terhadap Tingkat Kepatuhan Pada Pekerja informal Selama Pandemi Covid-19

MG Catur Yuantari ${ }^{1}$, Enny Rachmani ${ }^{2}$, Eti Rimawati ${ }^{1}$, Sri Handayani ${ }^{1}$, Edi Jaya Kusuma ${ }^{2}$

Peran Pengawas Minum Obat Dan Pendampingan Berobat Ulang Dengan Keberhasilan Pengobatan Tb Paru

Taswin $^{\left.1^{*}\right)}$, (zan $^{1)}$, Wahyuddin $^{1)}$, Dahmar ${ }^{1)}$

Faktor Determinan Sosial Dan Gambaran Kejadian Post Traumatic Syndrome Disorder (Ptsd) Pasca Banjir Di Dki Jakarta

Dan Bekasi Tahun 2020

Thresya Febrianti ${ }^{1}$, Nurfadhillah ${ }^{2}$, Mitha Nurhjanah ${ }^{3}$, Tiara Kautsa Aliefya ${ }^{4}$

Perbedaan Pola Makan Pada Balita Stunting Dan Tidak Stunting Di Kecamatan Teon Nila Serua (Tns) Kabupaten Maluku Tengah

Trixie Leunupun ${ }^{1}$, Ani Margawati' ${ }^{2}$ Annastasia Ediati ${ }^{3}$

Gambaran Pengelolaan Rekam Medis Rawat Inap Di Rsud Syekh Yusuf Kab. Gowa Tahun 2019

Zilfadhilah Arranury*, Surahmawati, Muhammad Rusmin, Tri Addya Karini, Dian Rezki Wijaya, Ranti Ekasari, Jihan Sulfitri

Analisis Risiko Kesehatan dalam Pemanfaatan Kemball Limbah Sludge Industri Makanan PT. X

Sri Slamet Mulyati ${ }^{1}$, Fajar Sihite ${ }^{2}$ 


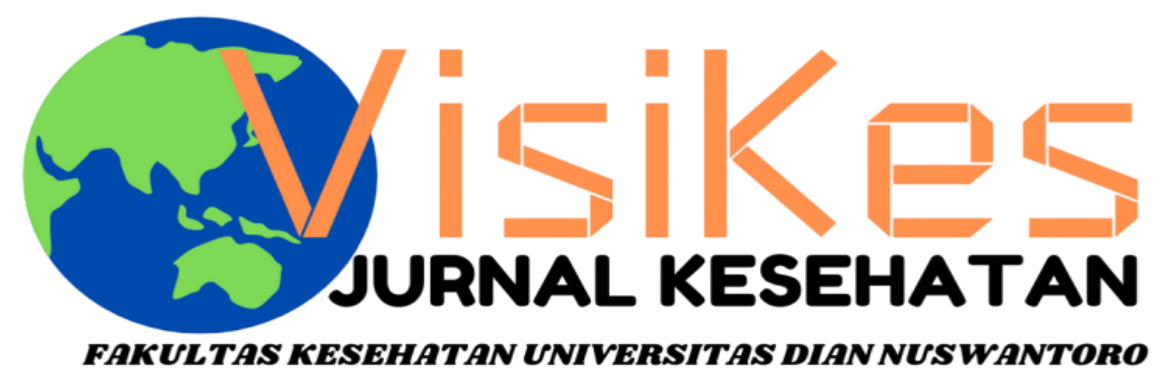

Volume 20, Nomor 1, April 2021

\section{Ketua Redaksi}

Dr. Drs. Slamet Isworo, M.Kes

\section{Penyunting}

Enny Rachmani, SKM, M.Kom, Ph.D

Fitria Wulandari, SKM, M.Kes

\section{Sekretariat}

Lice Sabata, SKM

Desain dan Layout

Puput Nur Fajri, SKM

\section{Alamat Redaksi}

Fakultas Kesehatan Universitas Dian Nuswantoro Jl. Nakula I No. 5-11 Semarang Telp/fax. (024) 3549948

email : visikes@fkes.dinus.ac.id

website $\quad$ : http://publikasi.dinus.ac.id/index.php/visikes/index

VisiKes diterbitkan mulai Maret 2002

Oleh Fakultas Kesehatan Universitas Dian Nuswantoro 


\title{
Peran Suami Dan Petugas Kesehatan Dengan Deteksi Dini Kanker Serviks
}

\author{
Christina Leasa, ${ }^{1}$ Mariene Wiwin Dolang ${ }^{1}$ \\ ${ }^{1}$ STIKES Pasapua Ambon \\ Email: marienedolang@gmail.com, Suli Raya-Wayari, Maluku Tengah
}

\begin{abstract}
Cervical cancer, including a disease that is quite dangerous that occurs in women. Cervical cancer is a health problem commonly suffered by women, so it needs attention. This study aims to determine the relationship between the role of husbands and health workers with early detection of cervical cancer in women of childbearing age at Benteng Community Health Center. The research design was analytic observational with cross sectional design. The sample in this study were 135 women of childbearing age aged 15-49 years in the Benteng Community Health Center. The results showed that there was a relationship between husband's peram $(p=0.005)$ and the role of health workers ( $p=0.005$ ) with early detection of cervical cancer in women of childbearing age at Benteng Community Health Center.
\end{abstract}

Keywords: Early detection of cervical cancer, husband Support, Health Workers

\begin{abstract}
ABSTRAK
Kanker serviks termasuk penyakit yang cukup membahayakan yang terjadi pada wanita. Penyakit kanker serviks merupakan masalah kesehatan yang biasa diderita pada wanita sehingga perlu mendapat perhatian. Penelitian ini bertujuan untuk mengetahui hubungan antara peran suami dan petugas kesehatan dengan deteksi dini kanker serviks pada wanita usia subur pada Puskesmas Benteng. Desain penelitian adalah analitik observasional dengan rancangan cross sectional. Sampel dalam penelitian ini adalah waita usia subur yang berusia 15-49 tahun di wilayah Puskesmas Benteng sebanyak 135 responden. Hasil penelitian didapatkan bahwa ada hubungan peram suami $(p=0,005)$ dan peran petugas kesehatan $(p=0,005)$ dengan deteksi dini kanker serviks pada wanita usia subur di Puskesmas Benteng.
\end{abstract}

Kata Kunci: Deteksi Dini Kanker Serviks, Peran Suami, Peran Petugas Kesehatan

\section{PENDAHULUAN}

Kanker serviks termasuk salah satu penyakit yang cukup membahayakan bagi wanita. Penyakit kanker serviks merupakan masalah kesehatan yang biasa diderita pada wanita sehingga perlu mendapat perhatian. (1) Kanker serviks salah satu penyakit yang sering menyerang wanita dan pada tahun 2018 diperkiraan terdapat 570.000 kasus baru. Diperkirakan angka kematian karena kanker serviks pada negara berpenghasilan menengah dan rendah sebanyak $90 \%$. Tingginya angka kematian yang disebabkan kanker serviks dapat dikurangi dengan beberapa pendekatan, seperti tindakan pencegahan, diagnosis secara dini, melakukan skrining yang efektif dan mengikuti program pengobatan. ${ }^{(2)}$ Data yang diperoleh dari Globacan (2012) mengatakan bahwa angka insiden kanker serviks di Indonesia sebanyak 20.928 kasus atau 17 per 100.000 wanita dan angka ini diatas rata-rata Asia 
Tenggara yaitu 10 per 100.000 wanita, karena angka kejadian dan kematian yang cukup tinggi, maka dibutuhkan penanganan yang lebih awal untuk menanggulangi masalah tersebut. ${ }^{(3)(4)}$

Berdasarkan data yang diperoleh dari Dinkes Maluku terdapat 43 kasus kanker serviks tahun 2014, meningkat 47 kasus (2015) dan pada tahun 2016 menurun sebanyak 35 kasus. Kejadian kanker serviks yang tinggi di Indonesia dikarenakan rendahnya kesadaran WUS untuk melakukan deteksi dini. Setiap wanita memiliki resiko untuk terkena kanker serviks tanpa melihat kondisi sosial, ekonomi, status, dan usia. ${ }^{(5)}$

Tingginya prevalensi kanker serviks pada wanita di Indonesia sehingga perlu dilakukan tindakan pencegahan dan deteksi dini yang dilakukan oleh penyedia pelayanan kesehatan. Tindakan pencegahan kanker serviks dapat dilakukan mengingat sel kanker serviks yang dapat diketahui pada stadium awal yaitu sel abnormal yang ditemukan pada permukaan serviks dapat diobati dengan tingkat kesembuhan hampir 100\%. Program deteksi dini yang dilakukan di Indonesia untuk mengurangi angka kejadian kanker serviks adalah dengan metode IVA test, yang tercantum dalam Keputusan Menteri Kesehatan Republik Indonesia tentang pedoman teknis pengendalian kanker serviks. Data deteksi dini kanker serviks yang di dapat di Maluku pada tahun 2016 sebanyak 21.712 wanita, dan meningkat pada tahun 2017 sebanyak 42.383 wanita, dan pada tahun 2018 sebanyak 99.051. Sedangkan pada tahun 2019 sebagai tahun terakhir akan dilakukan pemerikasaan gratis kepada 229.992 wanita di maluku.

Suartini tahun 2017 dalam penelitiannya mengungkapkan bahwa kejadian kanker serviks yang tinggi dikarenkan deteksi secara dini yang rendah, dimana sebanyak $69,4 \%$ WUS yang menderita kanker tidak pernah melakukan pap smear ataupun IVA Test sehingga kanker terdiagnosis pada stadium lanjut dan pengobatan sudah terlambat. ${ }^{(6)}$ Keluarga khususnya suami merupakan orang terdekat dan dapat mempengaruhi dalam pengambilan keputusan WUS. Peran suami dalam hal ini pemberian dukungan oleh suami dapat menjadi faktor penentu karena dengan adanya dorongan dari pasangan, maka akan memberikan penguatan kepada sang istri untuk melakukan deteksi dini kanker serviks. Suami dengan pemahaman yang lebih dapat memberikan penjelasan dan motivasi kepada istri untuk berprilaku sehat. ${ }^{(7)}$ Dukungan yang diberikan oleh suami, seperti pemberian informasi dapat mempengaruhi perilaku istri dalam memelihara kesehatannya. Dukungan pengharapan dalam bentuk ekspresi positif kepada istri sehingga istri mempunyai seseorang yang bisa diajak berkomunikasi tentang masalah yang dihadapi. Selain keluarga, Petugas kesehatan dapat mempengaruhi wanita untuk melakukan IVA test ataupun Pap Smear. Peran petugas kesehatan menurut kemenkes pada pencegahan kanker serviks dengan melaukan deteksi secara dini menggunakan IVA test 
yaitu memberi informasi tentang pemeriksaan IVA test yaitu memberi informasi tentang pemeriksaan IVA test serta mengajak WUS untuk melakukan pemeriksaan IVA test. Rendahnya kesadaran yang dimiliki oleh WUS yang melalakukan deteksi dini kanker serviks berdampak pada meningkatnya kasus kanker serviks secara terus menerus.

\section{METODE PENELITIAN}

\section{Rancangan Penelitian}

Penelitian observational analitik dengan rancangan Cross Sectional Study.

\section{Populasi dan Sampel}

Populasi di penelitian ini adalah semua WUS di Puskesmas Benteng dan berusia 1549 Tahun sebanyak 200 responden dan sampel sebanyak 135 responden dengan menggunakan accidental sampling.

\section{Teknik Pengumpulan Data}

Data dikumpulkan menggunakan kuesioner dan wawancara. Kuesioner deteksi dini, peran suami, dan peran petugas kesehatan menggunakan skala Guttman. Kuesioner pada penelitian ini merujuk ke kuesioner penelitian-penelitian serupa sebelumnya. Pengumpulan data dilakukan dengan metode wawancara mendalam kepada responden. Sebelum dilakukan penelitian, terebih dahulu peneliti membeikan inform concent atau lembar persetujuan menjadi responden.

\section{Cara Analisis Data}

Analisis data yaitu analisis univariat dan bivariat. Analisis univariat digunakan untuk menggambarkan distribusi frekuensi variabel, baik variabel dependen maupun variabel independen. Analisis bivariat digunakan untuk mengetahui hubungan variabel independen dan variabel dependen dengan menggunakan uji statistik chi square dengan tingkat kemaknaan a 0,05. Karena analisis menggunakan tabel $2 \times 2$ maka digunakan Continuity Correction dan jika terdapat nilai harapan sel $<5$, maka dinggunakan Fisher Exact dengan rumus.

HASIL

Penelitian ini dilaksanakan dari 2 Agustus sampai 4 September 2019 di Puskesmas Benteng Kota Ambon. Adapaun hasil penelitian sebagai tabel berikut:

Tabel 1. Distribusi Responden MenurutKarakteristik

\begin{tabular}{|c|c|c|}
\hline Karakteristik Responden & $\mathbf{n}$ & $\%$ \\
\hline \multicolumn{3}{|l|}{ Usia } \\
\hline$<20$ tahun & 13 & 9,6 \\
\hline 21-30 tahun & 59 & 43,7 \\
\hline 31-40 tahun & 45 & 33,3 \\
\hline 41-50 tahun & 18 & 13,3 \\
\hline \multicolumn{3}{|l|}{ Agama } \\
\hline Protestan & 120 & 88,9 \\
\hline Katolik & 15 & 11,1 \\
\hline \multicolumn{3}{|l|}{ Tingkat Pendidikan } \\
\hline $\mathrm{PT}$ & 49 & 36,3 \\
\hline SMA & 83 & 61,5 \\
\hline SMP & 3 & 2,2 \\
\hline Pekerjaan & 31 & \\
\hline PNS & 87 & 23,0 \\
\hline IRT & 17 & 64,4 \\
\hline Pegawai Swasta & & 12,6 \\
\hline Total & 135 & 100.0 \\
\hline
\end{tabular}

Sumber: Data Primer 2019

Data yang diperoleh pada tabel 1 mayoritas responden berusia 21-30 tahun sebanyak 59 orang $(43,7 \%)$. Untuk agama, lebih banyak responden yang beragama 
kristen protestan yaitu 120 responden $(88,9 \%)$. Kebanyakan respondenmempunyai tingkat pendidikan SMA sebanyak 83 responden $(61,5 \%)$ dan untuk pekerjaan ratarata responden sebagai IRT yang terdapat sebanyak 87 responden

$(64,4 \%)$

Tabel 2. Distribusi Responden Berdasarkan Variabel Penelitian

\begin{tabular}{ccc}
\hline Variabel Penelitian & $\mathbf{n}$ & $\%$ \\
\hline Dukungan Suami & & \\
Ya & 61 & 45,2 \\
Tidak & 74 & 54,8 \\
Peran Petugas Kesehatan & 66 & 48,9 \\
Ya & 69 & 51,1 \\
Tidak & 70 & 51,9 \\
Deteksi Dini & 65 & 48,1 \\
Tidak & $\mathbf{1 3 5}$ & $\mathbf{1 0 0 . 0}$ \\
\hline
\end{tabular}

Sumber: Data Primer 2019

Berdasarkan tabel 2 bahwa sebagian besar WUS tidak mendaptkan dukungan suami untuk mengikuti deteksi dini $(54,8 \%)$ dan demikian halya dengan peran petugas kesehatan dimana sebagian besar responden mengatakan tidak ada peran dari petugas kesehatan $(5,1 \%)$. Sebagian besar responden telah mengkuti deteksi dini yaitu sebesar $51,9 \%$ responden.

Tabel 3. Hubungan Peran Suami, dan Petugas Kesehatan Dengan Deteksi Dini Kanker Serviks di Puskesmas Benteng Ambon

\begin{tabular}{ccccccccc}
\hline & \multicolumn{4}{c}{ Deteksi dini } & \multicolumn{2}{c}{ Total } & \multirow{2}{*}{ Nilai $\mathrm{p}$} \\
\cline { 2 - 6 } Variabel & \multicolumn{3}{c}{ Ya } & \multicolumn{2}{c}{ Tidak } & & \\
\cline { 2 - 6 } & $\mathrm{n}$ & $\%$ & $\mathrm{n}$ & $\%$ & $\mathrm{n}$ & $\%$ & \\
\hline Peran Suami & 23 & 37,7 & 38 & 62,3 & 61 & 100.0 & \multirow{2}{*}{0,005} \\
Ya & 47 & 63,5 & 27 & 36,5 & 74 & 100.0 & \\
Tidak & & & & & & & \\
Peran Petugas Kesehatan & 23 & 34,8 & 43 & 65,2 & 66 & 100.0 & \multirow{2}{*}{0,000} \\
Ya & 47 & 68,1 & 22 & 31,9 & 69 & 100.0 & \\
Tidak & 70 & 51,9 & 65 & 48,1 & 135 & 100.0 & \\
\hline Total & & & & & &
\end{tabular}

Sumber: Data Primer 2019

Data yang diperoleh pada tabel 3 diketahui dari 61 responden yang mendapatkan peran dari suami terdapat $37,7 \%$ yang melakukan deteksi dini sedangkan yang tidak melakukan sebanyak 62,3\%. Hasil uji menggunakan Continuity Correction didapatkan nilai $p=0,005$, karena nilai $p<0,05$ maka Ho ditolak yang berarti ada hubungan antara peran suami dengan deteksi dini kanker serviks. Dari 66 responden dengan peran dari petugas kesehatan terdapat $34,8 \%$ yang melaksanakan deteksi dini dan dari 69 responden yang tidak mendapatkan peran dari petugas kesehatan terdapat $31,9 \%$ yang tidak melaksanakan deteksi dini. Hasil uji dengan menggunakan 
Continuity Correction diperoleh nilai $p=0,000$, karena nilai $p<0,05$ maka Ho ditolak yang berarti ada hubungan antara peran petugas kesehatan dengan deteksi dini kanker serviks.

\section{PEMBAHASAN}

\section{Peran Suami}

Keluarga maupun suami merupakan orang yang dapat mempengaruhi upaya deteksi dini kanker serviks. Suami merupakan orang terdekat yang dapat memengaruhi keputusan pasangan (WUS). Dukungan suami dalam bentuk dukungan sosial sebagai respon yang dapat dirasakan dan bermanfaat oleh anggota keluarga. Oleh sebab itu, suami yang memberikan dukungan kepada pasangan untuk melakukan deteksi dini kanker serviks dapat mendorong seorang wanita untuk berpartisipasi melaksanakan deteksi dini kanker serviks.

Peran yang diberikan suami, yaitu dengan memberikan informasi tentang kanker serviks, memberikan respon positif jika pasangan ingin berdiskusi tentang masalah kesehatan seperti kanker serviks. Suami yang baik dalam memberikan respon akan diikuti dengan memberikan biaya untuk melakukan pemeriksaan kesehatan dan suami juga tidak keberatan apabila pasangan meminta untuk diantarkan ke tempat fasilitas kesehatan. Sebagian besar suami yang memberikan dukungan yang positif akan berinisiatif terlebih dahulu untuk memotivasi responden untuk melakukan deteksi dini kanker serviks.

Hasil penelitian menunjukan bahwa secara statistik terdapat hubungan yang signifikan pada peran suami dengan deteksi dini kanker serviks. Hasil penelitian yang diperoleh menunjukan responden yang mendapatkan peran dari suami dan melakukan pemeriksaan deteksi dini kanker serviks sebanyak 23 responden $(37,7 \%)$ dan responden yang tidak mendapat dukungan suami tetapi melakukan pemeriksaan deteksi dini kanker serviks sebanyak 47 responden (63,5\%). Penelitian ini sejalan dengan penelitian Kurniawati (2015), dimana ada hubungan antara peran suami dengan WUS yang melaksanakan deteksi dini kanker serviks. Pada penelitian ini didapatkan hasil bahwa dukungan suami dalam kategori baik sebanyak 79 orang (84,0\%) sedangkan kategori kurang baik sebanyak 15 orang (16,0\%). Penelitian lain oleh Flora tahun 2016 dimana sang suami sangat berperan dalam pengambilan keputusan istri, dimana suami memiliki posisi tertinggi dalam keluarga dan sangat berpengaruh dalam setiap keputuan dalam keluarga termasuk dalam keputusan untuk melakukan pemeriksaan IVA. ${ }^{(8)}$ Wahyuni (2013) juga menyimpulkan bahwa suami yang memberikan dukungan dengan baik 3,05 kali dapat mengubah perilaku pasangan dalam mengikuti deteksi dini kanker serviks. ${ }^{(7)}$

\section{Peran Petugas Kesehatan}

Petugas Kesehatan diharapkan dapat melalukan pelayanan kesehatan secara baik untuk masyarakat sehngga derajat kesehatan dapat meningkat. Petugas kesehatan merupakan orang yang sangat berperan untuk memperoleh perilaku kesehatan yang lebih baik. Petugas kesehatan berperan 
dalam memberikan pemahaman yang baik tentang kanker serviks dan bagaimana pentingnya untuk melakukan deteksi dini. Selain itu, petugas kesehatan juga diharapakan dapat memberikan motivasi kepada wanita untuk melakukan deteksi dini.

Hasil penelitian ini menunjukan ada hubungan peran petugas kesehatan dengan deteksi dini kanker serviks. Hasil yang didapatkan pada penelitian menunjukan bahwa responden yang mendapat dukungan dari petugas kesehatan untuk melakukan pemeriksaan deteksi dini kanker serviks sebanyak 23 responden $(34,8 \%)$ dan yang tidak mendapat dukungan sebanyak 47 responden (68,1\%). Hasil analisis data dengan menggunakan uji chisquare bahwa ada hubungan peran petugas kesehatan dengan deteksi dini kanker serviks $(p=0,000)$,

Hasil penelitian sependapat dengan penelitian Sundari (2018) bahwa dukungan yang diberikan petugas kesehatan dapat mempengaruhi ibu dalam melakukan pemeriksaan IVA. Dimana lbu dengan dukungan yang baik dari petugas kesehatan sebagian besar melakukan pemeriksaan IVA. Petugas kesehatan berperan untuk memberikan pemahaman yang baik mengenai kanker serviks dan seberapa penting melakukan deteksi secara dini dan memotivasi WUS agar melakukan deteksi dini kanker serviks. ${ }^{(9)}$ Niluh tahun 2017 mengungkapkan bahwa paparan informasi yang kurang tentang pemeriksaan IVA yang diberikan petugas kesehatan menyebabkan PUS tidak mengetahui bahwa dirinya termasuk dalam kategori berisiko terkena kanker serviks,sehingga iya tidak akan menyadari bahwa dirinya rentan terhadap kanker serviks. ${ }^{(10)}$

\section{SIMPULAN DAN SARAN}

Hasil penelitian disimpulkan ada hubungan peran suami dan peran petugas kesehatan dengan deteksi dini kanker serviks.

Dari hasil penelitian diharapkan agar petugas kesehatan dapat lebih aktif dalam melakukan kegiatan konseling, informasi, dan edukasi kepada WUS dan dapat memberikan pelayanan yang lebih komperenhensif untuk peningkatan kesadaran WUS dalam melakukan IVA Test atau Pap Smear.

\section{DAFTAR PUSTAKA}

1. Sahr LA, Kusumaningrum TAI. Persepsi Dan Perilaku Wanita Usia Subur Dalam Melakukan Tes Inspeksi Visual Asam Asetat. J Promosi Kesehat Indones. 2018;13(2):114.

2. Nonik Ayu Wartini NI. Deteksi Dini Kanker Serviks Dengan Inspeksi Visual Asam Asetat (IVA). J Ners Dan Kebidanan. 2019;6(1):27-34.

3. Globocan WHO. Estimated Cancer Indance, Mortality And Prevalence Worldwide In 2012. International Agency For Research On Cancer (IARC) [Internet]. 2012. Available From: Http://Globocan.larc.Fr/Pages/Fact_Shee t\%0As_Population.Aspx.

4. Cancer) I (Information C On H And. Human Papilloma Virus And Related Disease Report For Indonesia. 2014.

5. Pusat Data Dan Informasi - Kementerian 
Kesehatan Republik Indonesia [Internet]. 2015. Available

From: Https://Pusdatin.Kemkes.Go.Id/Article/Vie w/15090700004/Situasi-PenyakitKanker.Html

6. Kebidanan J, Kesehatan P, Denpasar K. Studi Fenomenologi : Faktor-Faktor Yang Menyebabkan Wanita Usia Subur Tidak Menjalani Deteksi Kanker Serviks Dengan Tes Inspeksi Visual Asam Asetat ( Iva ) Di Provinsi Bali Ni Wayan Suarniti. 2017;7(1):1-8.

7. Dini D, Serviks K, Kecamatan DI. FaktorFaktor Yang Mempengaruhi Perilaku Deteksi Dini Kanker Serviks Di Kecamatan Ngampel Kabupaten Kendal Jawa Tengah. :55-60.

8. Parapat FT, S HS, Sc M, Saraswati LD,
Epid M. Faktor Faktor Yang Berhubungan Dengan Perilaku Deteksi Dini Kanker Leher Rahim Metode Inspeksi Visual Asam Asetat Di Puskesmas Candiroto Kabupaten Temanggung. 2016;4:363-70.

9. Sundari S, Setiawati E. Pengetahuan Dan Dukungan Sosial Mempengaruhi Perilaku Deteksi Dini Kanker Servik Metode Iva. Indones J Midwifery. 2018;1(1):6-11.

10. Niluh Nita Silfia Tm. Hubungan Karakteristik, Pengetahuan Dan Sikap Dengan Pemeriksaan Inspeksi Visual Asam Asetat (Iva) Pada Ibu Pasangan Usia Subur Di Puskesmas Talise. 2017;1(13):69-83. 